\title{
GEORGE III
}

Jeremy Black is professor of history at the University of Exeter. He is the author of biographies of William Pitt the Elder and of Sir Robert Walpole. Among his many publications are Maps and History (1997), War and the World (1998), Italy and the Grand Tour (2003) and The British Seaborne Empire (2004), all published by Yale University Press. He is a Fellow of the Royal Historical Society, Fellow of the Royal Society of Arts, and Member of the Order of the British Empire (MBE). 


\section{Also in the Yale English Monarchs Series}

ATHELSTAN by Sarah Foot

EDWARD THE CONFESSOR by Frank Barlow

WILLIAM THE CONQUEROR by David Douglas*

WILLIAM RUFUS by Frank Barlow

HENRY I by Warren Hollister

KING STEPHEN by Edmund King

HENRY II by W. L. Warren*

RICHARD I by John Gillingham

KING JOHN by W. L. Warren*

EDWARD I by Michael Prestwich

EDWARD II by Seymour Phillips

RICHARD II by Nigel Saul

HENRY V by Christopher Allmand

HENRY VI by Bertram Wolffe

EDWARD IV by Charles Ross

RICHARD III by Charles Ross

HENRY VII by S. B. Chrimes

HENRY VIII by J. J. Scarisbrick

EDWARD VI by Jennifer Loach

MARY I by John Edwards

JAMES II by John Miller

QUEEN ANNE by Edward Gregg

GEORGE I by Ragnhild Hatton

GEORGE II by Andrew C. Thompson

GEORGE III by Jeremy Black

GEORGE IV by E. A. Smith

* Available in the U.S. from University of California Press 


\section{GEORGE III AMERICA'S LAST KING}

Jeremy Black 
Copyright (C) 2006 Jeremy Black

First printed in paperback 2008

All rights reserved. This book may not be reproduced in whole or in part, in any form (beyond that copying permitted by Sections 107 and 108 of the U.S. Copyright Law and except by reviewers for the public press) without written permission from the publishers.

For information about this and other Yale University Press publications, please contact: U.S. Office: sales.press@yale.edu www.yalebooks.com

Europe Office: sales@yaleup.co.uk www.yalebooks.co.uk

Set in Baskerville by J\&L Composition, Filey, North Yorkshire

Printed in Great Britain by TJ International Ltd, Padstow, Cornwall

Library of Congress Cataloging-in-Publication Data

Black, Jeremy.

George III / Jeremy Black.

p. cm.- (Yale English monarchs)

Includes bibliographical references and index.

ISBN 0-300-II732-9

I. George III, King of Great Britain, I738-1820. 2. Great Britain-Politics and government - I760-I820. 3. Great Britain - Kings and rulers - Biography.

4. Monarchy - Great Britain - History. I. Title. II. Series.

DA506.A2B53 2006

941.07'3092- dc22

[B]

A catalogue record for this book is available from the British Library.

2006014067

ISBN 978-0-300-I362I-o (pbk)

I0 98765432 I

Published with assistance from the Annie Burr Lewis Fund. 
for Philadelphia friends 
